\title{
IMPLEMENTASI IBEACON DALAM RUANGAN UNTUK MEMPROMOSIKAN PRODUK DENGAN TEKNOLOGI BLUETOOTH LOW ENERGY (BLE) PADA EIGHTMART
}

\author{
Desmira $^{1}$ \\ Pendidikan Vokasional Teknik Elektro, Fakultas Keguruan dan Ilmu Pendidikan \\ Universitas Sultan Ageng Tirtayasa, Serang 42117, Indonesia \\ E-mail:desmira@untirta.ac.id
}

\begin{abstract}
S : Eightmart is a minimarket in the main lobby at Serang Raya University that provides the needs of students while on campus. By understanding consumer behavior in the current digital era that cannot be separated from smartphones, the management is trying to make a new breakthrough by promoting goods sold at Eightmart using Smartphones and making hotspot connections available for free and providing comfortable seats and tables for learn while enjoying the food at Eightmar. The purpose of this research is to produce an application for visitors and students to get information with relevant content according to the location where they are. The benefit of this research is that Eightmart management can promote products that have price cuts. Researchers can notify smartphone users of product promos where they are near the provider of goods or services at that time (realtime). The test was carried out by connecting a smartphone at a location using Bluetooth LE technology and trying it on smartphone consumers, by testing with two smartphones with the first specification on a smartphone with $2 \mathrm{~GB}$ ram specifications with marshmellow OS specifications and the second with 512 ram smartphones and kitkat OS. The research method in this research is observation, interviews and literature study with a waterfall model development model. The results of the study The maximum Bluetooth connection distance that has been tested on two different smartphones and the minimum use in Bluetooth LE is operated on 4.4 kitkat, so the signal strength results are different in the two operating systems. In the cubeacon application on the samsung J1 ace, the signal range is about 12.3 meters, and on the samsung xiaomi redmi $4 a$ it is about 16.5 meters.
\end{abstract}

Keywords: Wireless technology, Ibeacon, Bluetooth Low technology.

ABSTRAK: Eightmart merupakan minimarket yang ada dilobi utama yang berada di Universitas Serang Raya yang menyediakan kebutuhan mahasiswa ketika berada dikampus. Dengan memahami perilaku konsumen diera digital saat ini yang tidak lepas dari smartphone maka pihak manajemen berusaha membuat suatu trobosan baru dengan mempromosikan barang-barang yang dijual di Eightmart dengan menggunakan Smartphone serta membuat koneksi hospot selaku tersedia dengan gratis dan menyediakan tempat duduk dan meja yang nyaman buat belajar sambil menikmati makanan yang ada di Eightmar. Tujuan dari penelitian ini adalah menghasilkan aplikasi bagi pengunjung dan mahasiswa untuk mendapatkan informasi dengan konten yang relevan sesuai dengan lokasi dimana mereka berada. Manfaat dari penelitian ini adalah menejemen Eightmart dapat mempromosikan produk yang ada pemotongan harga .Peneliti dapat menginformasikan promo produk kepada pengguna smartphone dimana mereka berada di dekat penyedia barang atau jasa saat itu juga (realtime). Pengujian dilakukan dengan menghubungkan smartphone di lokasi dengan memanfaatkan teknologi Bluetooth LE dan di coba pada smartphone konsumen, dengan melakukan pengujian dengan dua smartphone dengan spesifikasi berbeda, yang pertama pada smartphone dengan spesifikasi ram 2GB dengan OS marshmellow dan yang kedua dengan smartphone ram 512 dan OS kitkat. Metode penelitian dalam penelitian adalah observasi,wawancara dan studi literature dengan model mengembangkan model air terjun atau waterfall . Hasil dari penelitian Jarak koneksi Bluetooth maksimum yang telah di uji pada kedua smartphone berbeda dan penggunaan dalam Bluetooth LE minimum di operasikan pada 4.4 kitkat, sehingga hasil kekuatan sinyal ternyata berbeda pada kedua sistem operasi tersebut. Pada aplikasi cubeacon yang ada di samsung J1 ace jangkauan sinyal nya yaitu sekitar 12,3 meter, dan pada samsung xiaomi redmi 4a yaitu sekitar 16,5 meter.

Kata Kunci: Teknologi nirkabel, Ibeacon, teknologi Bluetooth Low.

\section{PENDAHULUAN}

Us niversitas Serang Raya adalah sebuah kampus swasta yang terletak di provinsi Banten. Universitas Serang Raya memiliki tatanan gedung yang luas dan ruangan untuk perkuliahan mahasiswa dan dosen, dan memiliki toko belanja di dalamnya bernama Eightmart. Eightmart menggabungkan kebutuhan pokok serta buku bagi mahasiswa, pelajar dan umum untuk mempermudah dalam mencari buku sambil berbelanja. Sejalan pengembangan operasional toko, perusahaan tertarik untuk lebih mendalami dan memahami berbagai kebutuhan perilaku konsumen dalam berbelanja. Guna mengakomodasi tujuan tersebut, beberapa karyawan ditugaskan untuk mengamati dan meneliti perilaku belanja masyakarakat.

Bluetooth LE atau yang dikenal juga dengan nama Bluetooth smart adalah sebuah teknologi nirkabel personal yang diciptakan untuk mengurangi konsumsi tenaga namun memiliki jarak komunikasi data yang sama dengan Bluetooth sebelumnya sehingga dimungkinkan untuk aplikasi yang membutuhkan komunikasi data tingkat tinggi namun memiliki daya atau tenaga listrik yang terbatas seperti pada smartphone pintar. Kelebihan lain nya adalah pada modul Bluetooth ini lebih kecil dari pada pendahulunya, sehingga dapat di

\footnotetext{
${ }^{1}$ Pendidikan Vokasional Teknik Elektro, Fakultas Keguruan dan Ilmu Pendidikan Universitas Sultan Ageng Tirtayasa
} 
tanam pada perangkat perangkat yang memiliki ukuran dan ruang yang terbatas.

Salah satu yang sedang dikembangkan adalah sensor kedekatan yang diberi nama iBeacon. Teknologi ini memungkinkan untuk melacak pada jarak tertentu dan menangkap informasi yang dipancarkan tersebut, sehingga selain dapat mengetahui informasi produk secara detail, Karena di UNSERA sendiri belum pernah ada share lokasi dengan teknologi nirkabel. Hal ini memungkinkan Bluetooth smart menjadi sebuah GPS (Global Positioning System) lokal tanpa memerlukan koneksi internet dan dengan konsusmsi daya yang rendah. Dengan teknologi tersebut, memungkinkan dikembangkan aplikasi untuk location based mobile advertising sebagai solusi promosi produk di Eightmart untuk pengunjung/mahasiswa.

\section{KAJIAN PUSTAKA}

Smartphone dilengkapi dengan WiFi, Bluetooth, MEMS-IMU, dan lainnya sensor adalah platform yang sempurna untuk menyediakan layanan berbasis lokasi bagi pengguna pribadi [1]. iBeacon dibangun di atas Bluetooth Hemat Energi (BLE), ini mewakili solusi hemat daya yang sangat tinggi. Selain itu, teknologi iBeacon memiliki karakteristik level yang baik kompatibilitas dan portabilitas, mendukung perangkat berbasis iOS dan Android. Pendekatan yang diusulkan telah divalidasi secara nyata lingkungan dengan sistem prototipe dirilis sebagai open source yang menunjukkan bagaimana teknologi ini cocok untuk deteksi okupansi di bangunan pintar [2].

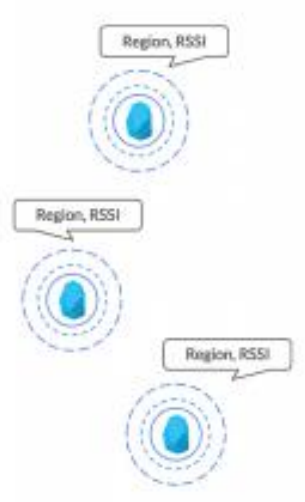

Beacons

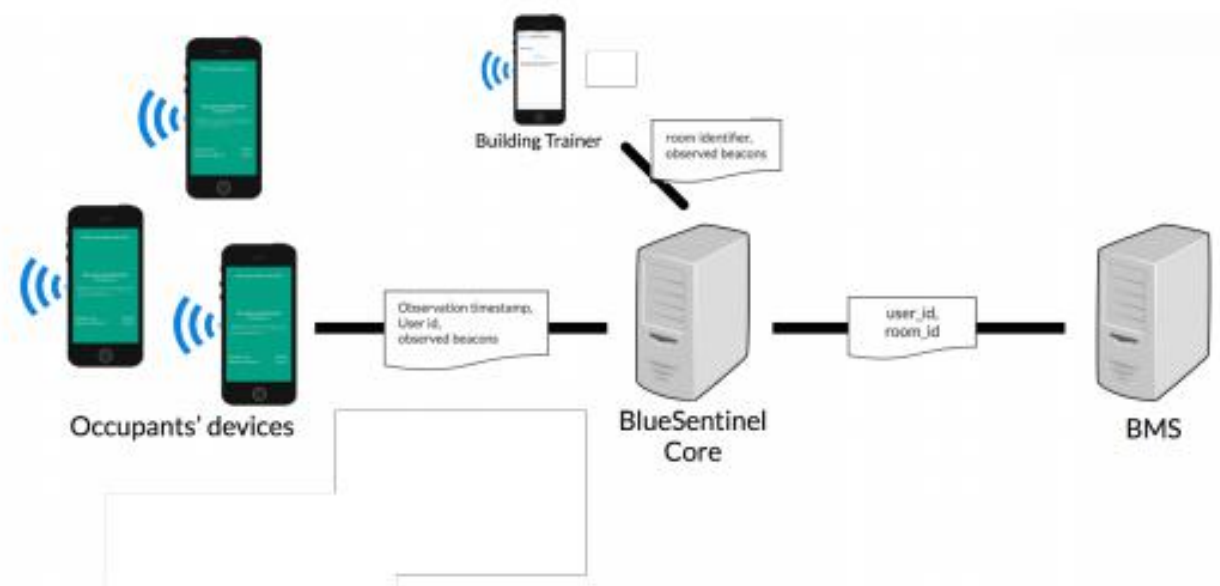

Gambar 1. Arsitektur BLUE-SENTINEL (termasuk antarmuka dengan layanan eksternal seperti Sistem Manajemen Gedung)

Dalam penelitiannya terdahulu mengusulkan solusi baru berdasarkan iBeacon teknologi. Solusi ini berbeda dari yang sebelumnya karena memanfaatkan standar Bluetooth Hemat Energi, yang memberikan konsumsi daya yang lebih rendah. Apalagi iBeacon protokol dapat digunakan baik pada sistem iOs dan Android, menjadikan pendekatan baru ini portabel. Berbeda dari kami pekerjaan sebelumnya berdasarkan perangkat iOS, dalam makalah ini kami fokus pada sebuah Solusi berbasis Android dengan tujuan meningkatkan akurasi lokasi dan efisiensi energi dari seluruh sistem. Kita meningkatkan akurasi sebesar 10\% dan efisiensi energi sebesar $15 \%$ [3]. Jarak sangat mempengaruhi informasi sampai pada tujuan yang diharapkan dengan menggunakan teknologi iBeacons, yang merupakan jenis energi rendah Gadget Bluetooth yang diusulkan oleh Apple. Array iBeacons diterapkan di file lingkungan dalam ruangan untuk secara berkala memancarkan sinyal yang dapat diterima oleh smartphone telepon. Jarak antara smartphone dan iBeacons dapat diperoleh oleh model rentang RSSI (Received Signal Strength Indication). Posisinya bisa dihitung berdasarkan algoritma pemosisian tiga bola setiap kali tiga atau lebih banyak sinyal diterima. Banyak eksperimen telah dilakukan dan Hasil menunjukkan bahwa akurasi posisi dapat diperoleh kurang dari 1,1 m. Jadi,sistem dapat memenuhi persyaratan dari banyak aplikasi pemosisian dalam ruangan scenario [4]. Lokasi dan status kontekstual (dalam atau luar ruangan) adalah fundamental dan kritis informasi untuk aplikasi lapisan atas, seperti pengenalan aktivitas dan layanan berbasis lokasi (LBS) untuk individu. Selain itu, optimalisasi sistem manajemen gedung (BMS), seperti proses pra-pendinginan atau pemanasan sistem pendingin udara sesuai dengan lalu lintas manusia yang masuk atau keluar dari gedung, dapat memanfaatkan informasi juga.

Perangkat seluler yang muncul, yaitu dilengkapi dengan berbagai sensor, menjadi platform yang layak dan fleksibel untuk melakukan indoor-outdoor (IO) deteksi. Namun, sensor yang haus daya, seperti GPS dan 
WiFi, harus digunakan dengan hati-hati karena penyimpanan baterai yang terbatas pada perangkat seluler. Dalam penelitian ini mengusulkan BlueDetect: akurat, cepat respons dan skema hemat energi untuk deteksi IO dan LBS yang berjalan lebih baik di seluler perangkat yang didasarkan pada teknologi iBeacon berdaya rendah yang sedang berkembang. Dengan memanfaatkan Bluetooth secara luas modul dan algoritma yang kami usulkan, BlueDetect menyediakan layanan deteksi IO yang tepat yang dapat berubah on / off on-board sensor haus daya secara cerdas dan otomatis, optimalkan kinerjanya dan kurangi konsumsi daya perangkat seluler secara bersamaan. Apalagi positioningnya mulus dan layanan navigasi dapat direalisasikan olehnya, terutama di lingkungan semi-outdoor, yang mana tidak dapat dicapai dengan GPS atau sistem pemosisian dalam ruangan (IPS) dengan mudah. Perangkat seluler Android dan mengevaluasi kinerjanya secara komprehensif. Hasil percobaan telah memvalidasi keunggulan BlueDetect dalam hal akurasi deteksi IO, akurasi lokalisasi dan konsumsi energy[5].
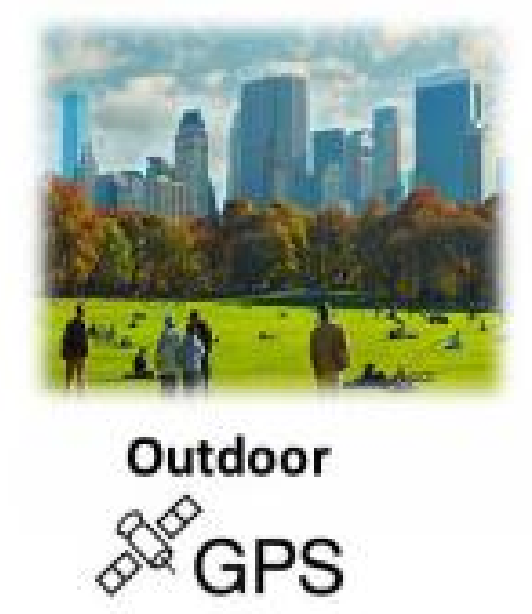
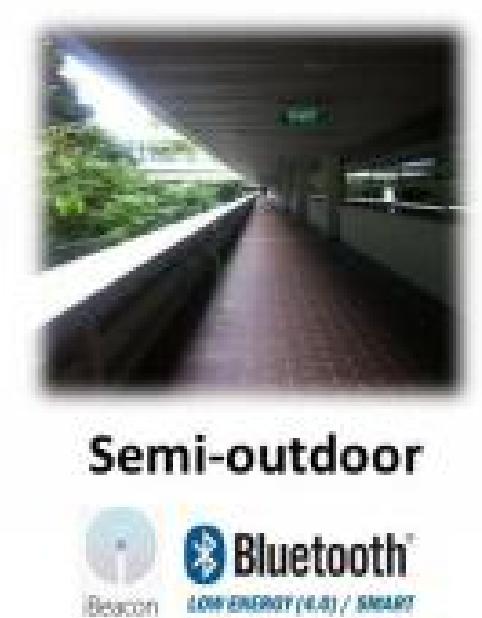

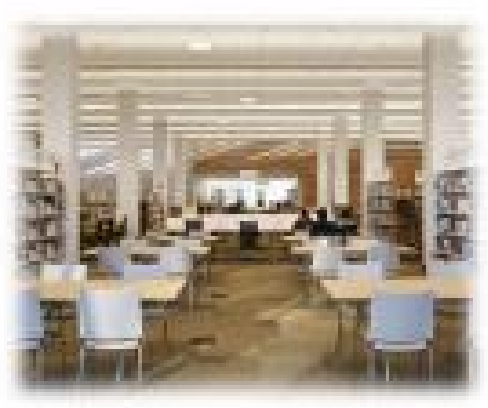

Indoor

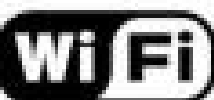

Gambar 2. Pemandangan representatif dan teknologi lokalisasi yang sesuai dari tiga lingkungan berbeda

Komunikasi backscatter menjanjikan hal yang signifikan keunggulan daya dan kompleksitas untuk perangkat Internet of Things seperti tag identifikasi frekuensi radio (RFID) dan nirkabel node sensor. Salah satu kelemahan yang dirasakan dari komunikasi backscatter adalah kebutuhan untuk perangkat keras khusus seperti itu sebagai pembaca RFID untuk menerima sinyal hamburan balik. Dalam makalah ini, kami menunjukkan bagaimana sinyal hamburan balik dapat dirancang untuk kompatibilitas dengan chipset Bluetooth 4.0 hemat energi (BLE) hadir di miliaran smartphone pintar dan tablet. Kami hadir prototipe tag "BLE-Backscatter" berbasis mikrokontroler itu menghasilkan modulasi penguncian pergeseran frekuensi bandpass pada $1 \mathrm{Mb} / \mathrm{s}$, memungkinkan kompatibilitas dengan saluran periklanan BLE konvensional. Menggunakan daya radiasi isotropis setara $+23-\mathrm{dBm}$ sumber pembawa gelombang kontinu $(\mathrm{CW})$, kami mendemonstrasikan rentang hingga $13 \mathrm{~m}$ antara tag dan Apple iPad Mini yang tidak dimodifikasi sebagai serta PC dengan chipset Nordic Semiconductor nRF51822. Dengan tag $1 \mathrm{~m}$ dari penerima, kami mendemonstrasikan berbagai hingga $30 \mathrm{~m}$ antara sumber pembawa CW dan tag. Di keduanya kasus, tumpukan Bluetooth yang ada digunakan, tanpa modifikasi apa pun untuk perangkat keras, firmware, atau perangkat lunak. Hamburan balik tag hanya mengkonsumsi 1,56 $\mathrm{nJ} / \mathrm{b}$, lebih dari $6 \times$ kurang dari daya terendah pemancar Bluetooth komersial [6]. 


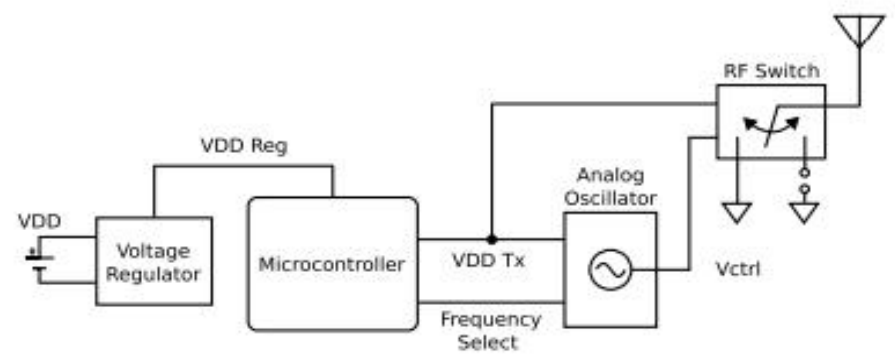

(a)

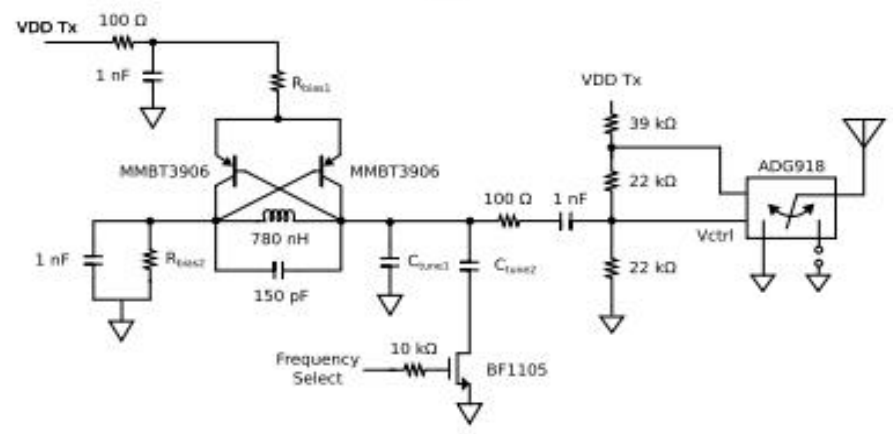

Gambar 3. (a) Diagram blok dari tag BLE-Backscatter. (b) Diagram sirkuit osilator analog dan sakelar RF modulasi.

Modul yang sangat terintegrasi ini sangat penting untuk kinerjanya dan efek yang dihasilkan dibahas. A berfungsi penuh prototipe berhasil dibuat dan diuji, menunjukkan solusi yang baik untuk Aplikasi Bluetooth. (C) 2006 Wiley Periodicals, Inc. Int J RF dan Microwave CAE 16: 238 -244, 2006 [7] . Model air terjun adalah proses desain sekuensial, sering digunakan dalam pengembangan perangkat lunak proses, di mana kemajuan dipandang mengalir dengan mantap ke bawah (seperti air terjun) melalui fase-fase [8]. Model Air Terjun merupakan pengembangan sekuensial model. Analysis Persyaratan harus jelas sebelum melanjutkan ke berikutnya fase desain. Pengujian dilakukan setelah kode selesai dibuat dikembangkan. Setiap produk kerja atau aktivitas selesai sebelum melanjutkan ke berikutnya. Setiap tahap perkembangan berlangsung secara berurutan tanpa tumpang tindih. Setiap fase jadwal untuk menyelesaikan tugas dalam jangka waktu tertentu.

Dokumentasi dan pengujian dilakukan di akhir setiap fase, yang membantu dalam menjaga kualitas pekerjaan. Dalam model air terjun, setiap langkah-langkah harus diselesaikan sebelum langkah berikutnya. Itulah persyaratan yang harus diikuti sebelumnya desain dimulai, dan setelah desain selesai pengkodean dimulai, dll. Tapi apa yang akan dilakukan tim penguji sampai saat itu sangat memakan waktu dan biaya tinggi.

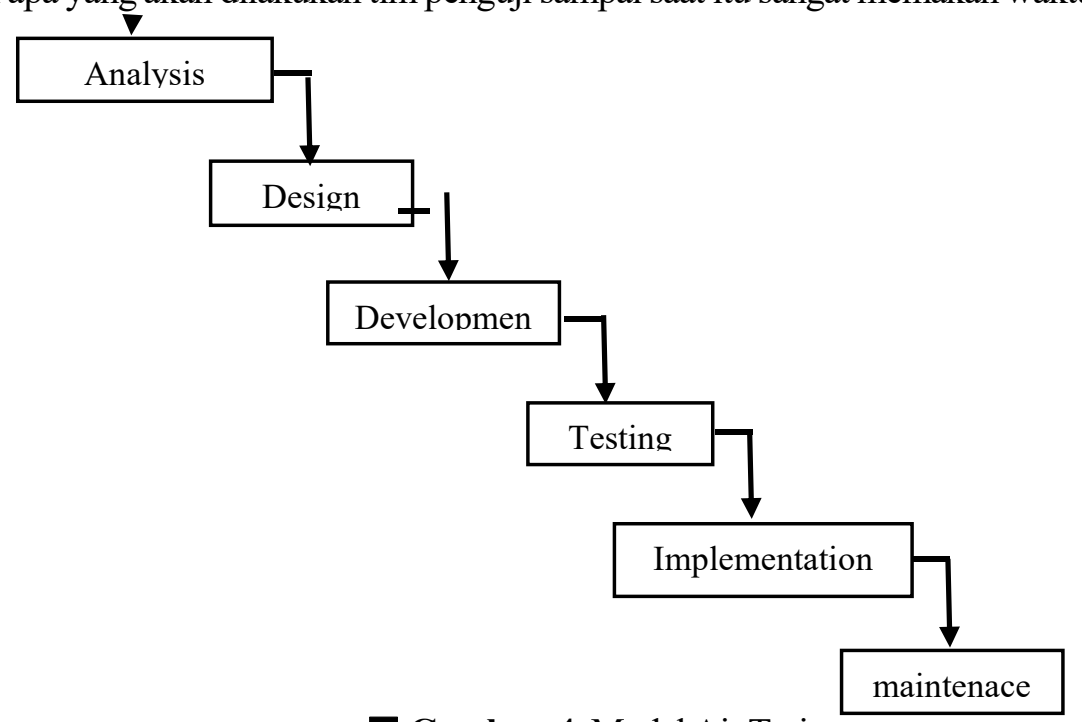

Gambar 4. Model Air Terjun 


\section{METODE PENELITIAN}

1. Observasi

Dengan melihat secara langsung kelokasi tempat yang dijadikan target penelitian yaitu dilobby utama lantai dasar Universitas Serang Raya.

2. Wawancara

Setelah melihat tempat dan lokasi Eightmart di lobby utama yang semua aktivitas mahasiswa di sana sehingga diadakan wawancara dengan pemilik usaha Eight mart.

3. Literatur pustaka

Setelah data didapatkan dengan dari hasil wawancara dan observasi maka tahap selanjutnya adalah mengadakan literatur pustaka yang membahas tentang tema yang akan dijadikan rujukan nantinya dalam membangun sistem dengan menggunakan model air terjun.

\section{HASIL DAN PEMBAHASAN}

Keamanan jaringan dengan firewall berbasis mikrotik sudah di terapkan pada sistem kemanan di Universitas Serang Raya. Spesifikasi untuk hardware menggunakan CPU x3100 M5, dengan keandalan performa di menara server tower $4 \mathrm{U} / 5 \mathrm{U}$ yang memberikan kinerja kelas bisnis, efisiensi energi, dan kehandalan di menaranya, dengan keunggulan sebagai berikut.

1. Didukung oleh prosesor Intel ${ }^{\circledR}$ terbaru.

2. Memori hemat energi hemat energi.

3. Kemampuan hot-swap hard drive.

4. Built-in data protection.

5. Pilihan penyimpanan yang fleksibel.

Untuk sistem x3100 m5 memiliki fitur sebagai berikut:

1. Memberikan kemampuan kinerja baru, didukung oleh prosesor Intel ${ }^{\circledR}$ dan memori hemat energi hemat energi.

2. Pengamanan dan meningkatkan bisnis yang berkembang dengan kemampuan hot-swap hard drive, kit peningkatan suhu operasi $40^{\circ} \mathrm{C}$, empat slot PCIe, pilihan penyimpanan, dan pilihan fleksibel.

3. Menawarkan perlindungan data built-in dengan maksimal empat tingkat RAID dan keandalan dari System $x^{\circledR}$.

4. Kemampuan kinerja, didukung oleh prosesor Intel (pilihan prosesor Intel Xeon ${ }^{\circledR}$ seri E3-1200 v3, Core $^{\mathrm{TM}}$ i3, Pentium ${ }^{\circledR}$, atau Celeron $\left.{ }^{\circledR}\right)$.

5. Memori hemat energi hemat energi.

6. Temperatur operasi yang dapat diupgrade (sampai $40^{\circ} \mathrm{C}$ ) dengan kit peningkatan suhu opsional untuk efisiensi energi yang optimal.

7. Built-in perlindungan data dengan sampai empat tingkat RAID dan keandalan yang Anda harapkan dari System x: Standard ServeRAID -0, -1, -10, plus RAID-5 tersedia melalui Fitur on Demand.

8. Pilihan penyimpanan yang fleksibel hingga kapasitas 24 TB: 4 × 3,5 inci atau 8 × 2,5 inci hard disk drive (HDD), ditambah opsi hot-swap untuk meminimalkan downtime. Dan untuk software nya menggunakan hotspot di linux ubuntu.

Pada topologi di bawah ini jaringan Bluetooth LE pada aplikasi cubeacon menggunakan topologi star dapat ditunjukan pada gambar 5 yang diimplementasikaan dalam penelitian ini. Pada tahap penelitian ini iBeacon melakukan output dan input, untuk peripheral device sendiri yaitu perangkat yang berada di sekitar cubeacon, ketika pengunjung membuka aplikasi maka tombol untuk menyalakan Bluetooth akan muncul, lalu aplikasi akan scanning cubeacon terdekat, ketika muncul gambar cubeacon pada aplikasi otomatis cubeacon tersebut melakukan input ke smartphone pengunjung untuk menampilkan promo produk, jarak, dan petunjuk. 


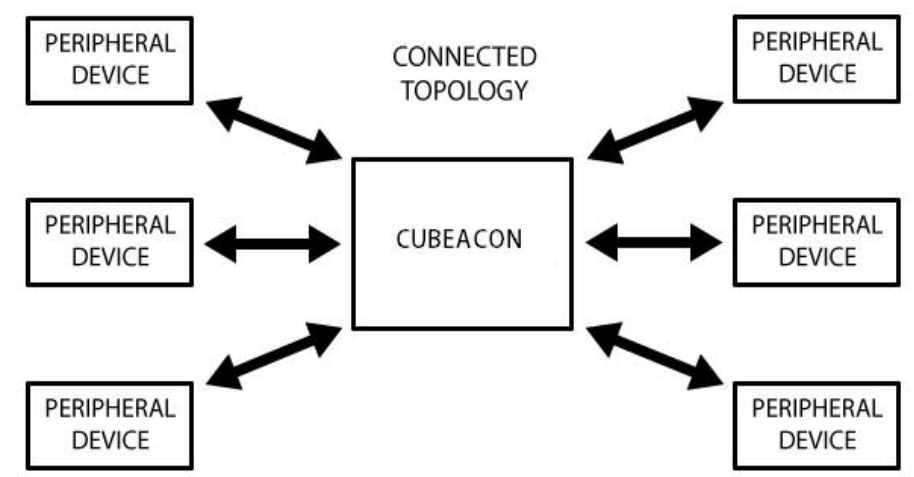

1. Keamanan Jaringan BLE

Gambar 5. Connected Topology

Pada keamanan jaringannya, Bluetooth LE pada iBeacon menggunakan AES security ( Advanced Encryption Standart), untuk melindungi informasi rahasia yang diimplementasikan dalam perangkat lunak dan perangkat keras untuk mengenkripsi data, dengan kode algoritma tertentu yang dinilai berdasarkan kemampuan untuk melawan serangan, sehingga aman untuk penggunanya, maka kekhawatiran masalah virus yang masuk ke smartphone bahkan data akan tercuri tidak terjadi.

2. Skema dan Rangkaian Proses Teknologi iBeacon

Teknologi memiliki jangkauan yang berkisar beberapa sentimeter sampai 10 meter atau lebih. Jarak pada perangkat smartphone didefinisikan dalam wilayah, dan setiap wilayah dapat diklasifikasikan sebagai "langsung" (beberapa sentimeter), "dekat" (beberapa 0 meter) dan "jauh" (lebih dari 20 meter). Setiap perangkat yang masuk ke suatu wilayah akan menerima pemberitahuan.

Rangkaian proses pada iBeacon ini adalah pengunjung terlebih dahulu mempunyai aplikasinya dengan cara mengunduh di www.sikembar.net/Eightmart, pada tahap selanjutnya pengunjung membuka aplikasinya dan memilih tiap submenu yang tersedia seperti promo produk, jarak, dan petunjuk. Ketika salah satunya sudah di klik maka akan ada perintah untuk menyalakan Bluetooth dan GPS, setelah itu proses scanning akan muncul, pada tahap ini aplikasi akan mencari alat cubeacon box dengan jangakuan Bluetooth LE yaitu antara 15 sampai 20 meter, lalu setiap perangkat yang masuk ke suatu wilayah jangkauan Bluetooth nya akan menerima pemberitahuan berupa promo eightmart, jarak dan tampilan petunjuk berupa denah.

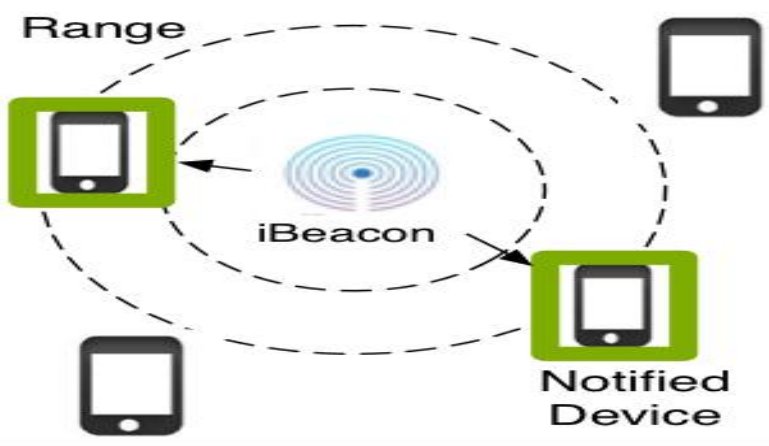

Gambar 6. iBeacon

\subsection{Perancangan Aplikasi waterfall}

1. Analysis

Analisa kebutuhan berdasarkan kebutuhan prangkat keras dan perangkat lunak. Kebutuhan Perangkat Keras dibutuhkan dalam pengujian aplikasi ini yaitu :

1. Telepon pintar (Smartphone) berbasis android dengan Bluetooth versi 4.0.

2. Laptop untuk perancangan aplikasi

Perancangan Activity Diagram merupakan perangkat lunak dan merupakn proses pengumpulan kebutuhan dilakukan secara intensif untuk menspesifikasikan kebutuhan perangkat lunak agar dapat dipahami perangkat lunak seperti apa yang dibutuhkan oleh user. Di dalam sistem aplikasi android location based mobile advertising ini diperlukan fungsi dengan spesifikasi sebagai berikut: 
a. Mampu menampilkan iklan format gambar dan teks pada aplikasi melalui perantara iBeacon Bluetooth Low Energy.

b. Mampu menampilkan jarak iBeacon di smartphone berupa meter dan dalam bentuk denah, dan melihat jangkauan maksimum jarak pada smartphone.

c. Menampilkan petunjuk jalan untuk sampai ke Eighmart

Proses mendapatkan promo produk terdapat mekanisme penunjung harus mengaktifkan Bluetooth dan GPS serta berada di area cakupan sinyal iBeacon, karena aplikasi iBeacon bluetooth low energy ini akan bekerja sesuai dengan keberadaan di mana iBeacon diletakkan

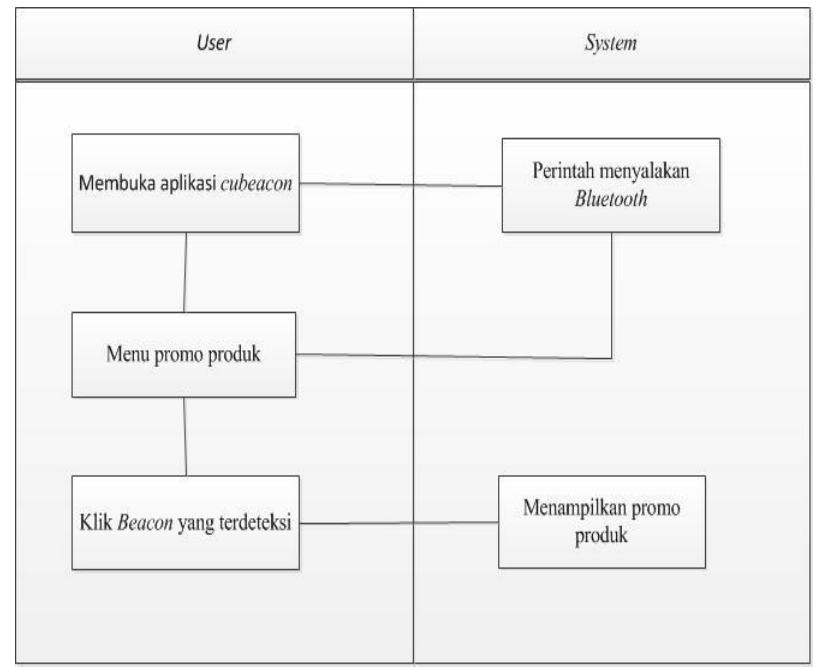

Gambar 7. Perancangan Activity Diagram

Berikut adalah tampilan menu ketika awal memasuki aplikasi Android, di tampilan awal halaman aplikasi terdapat beberapa sub menu, di antaranya, promo produk, jarak, profil pengembang, petunjuk, pembelian cubeacon, dan logo unsera, untuk menambah/mengubah logo/gambar pada tiap sub menu di menu utama maka harus mengedit pada project struktur di android, dengan memasuki file res-drawable. Untuk menambah kata atau mengubah kata pada tiap sub menu dengan memilih pilihan pada menu res-valuesstring.xml.

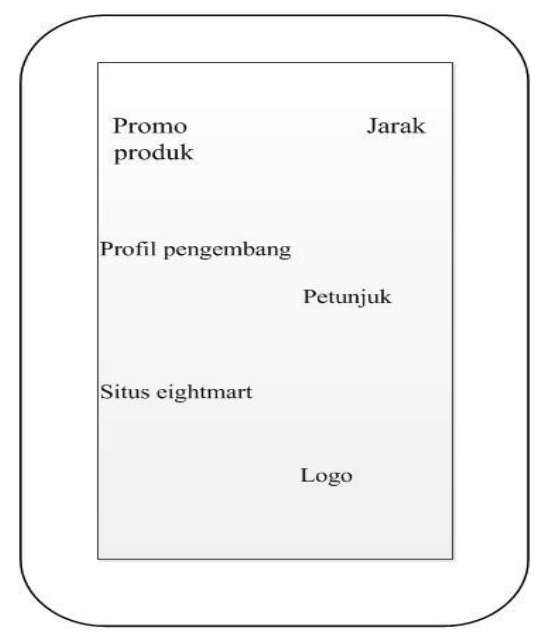

Gambar 8. Tampilan awal halaman aplikasi 


\section{Design}

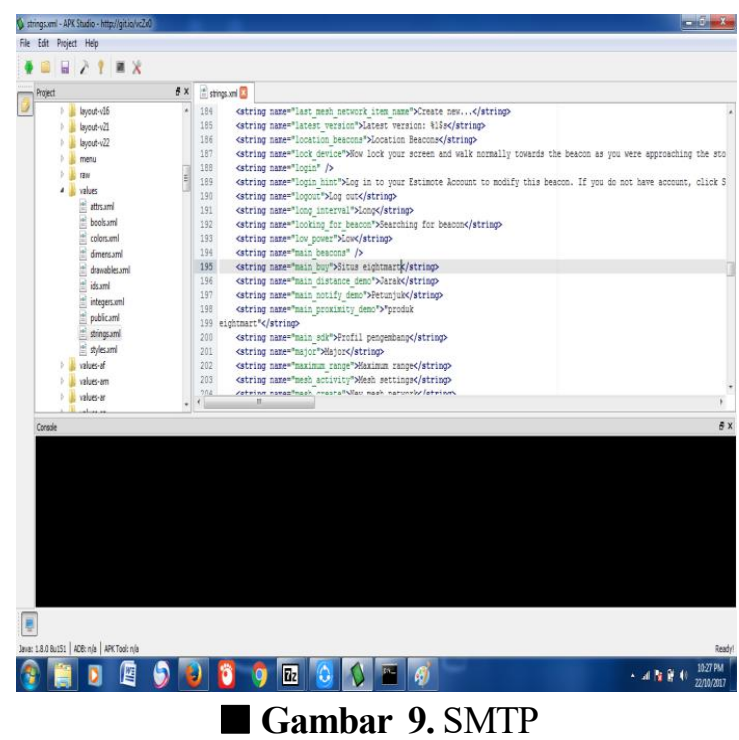

Desain perangkat lunak adalah proses multi langkah yang fokus pada desain pembuatan program perangkat lunak termasuk struktur data, arsitektur perangkat lunak, representasi antarmuka, dan prosedur pengodean. Tahap ini mentranslasikan kebutuhan perangkat lunak dari tahap analisis menjadi representasi desain agar dapat diimplementasikan menjadi program pada tahap selanjutnya.

3. Development

Pembuatan kode program harus ditranslasikan ke dalam program perangkat lunak. Hasil dari tahap ini adalah program komputer sesuai dengan desain yang telah dibuat pada tahap desain.

4. Testing

Pengujian fokus pada perangkat lunak secara logika dan fungsional dan memastikan bahwa semua bagian sudah diuji. Hal ini dilakukan untuk meminimalisir kesalahan (error) dan memastikan keluaran yang dihasilkan sesuai dengan yang diinginkan. Pada tampilan menu utama akan menampilkan tiap sub-sub menu pada aplikasi seperti sub menu produk Eighmart, jarak, petunjuk, profil pengembang, dan pembelian alat cubeacon nya, pengunjung/ user dapat memilih salah satu menu yang di tampilkan.

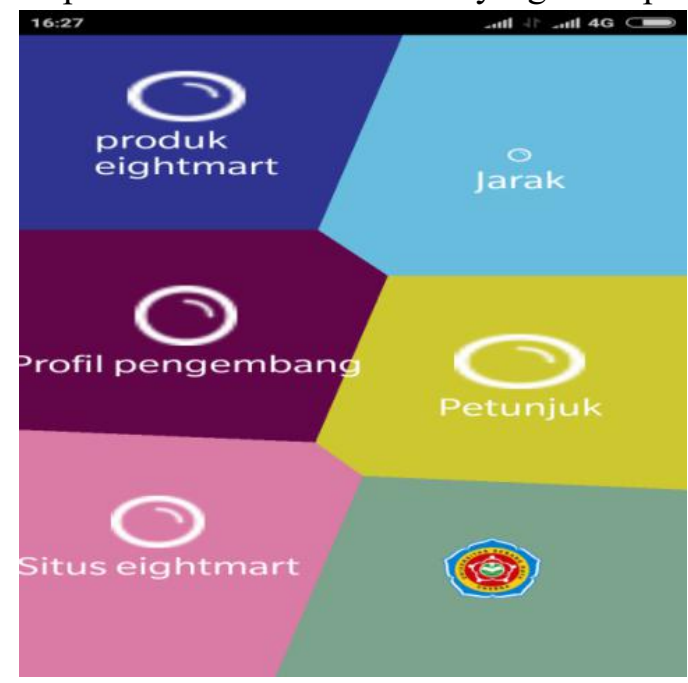

Gambar 10. Tampilan Menu Utama

Pada tampilan promo produk, pengunjung dapat memilih sub menu berupa produk Eightmart dan akan ditampilkan promo yang terdeteksi oleh aplikasi berupa gambar dan detail promo, pengunjung juga dapat langsung melihat detail promo dengan cara menekan menu produk Eighmart tersebut, dan untuk mengganti promo yang ada di lakukan pada project android dengan memasuki folder res-drawable xhdpi v4. 


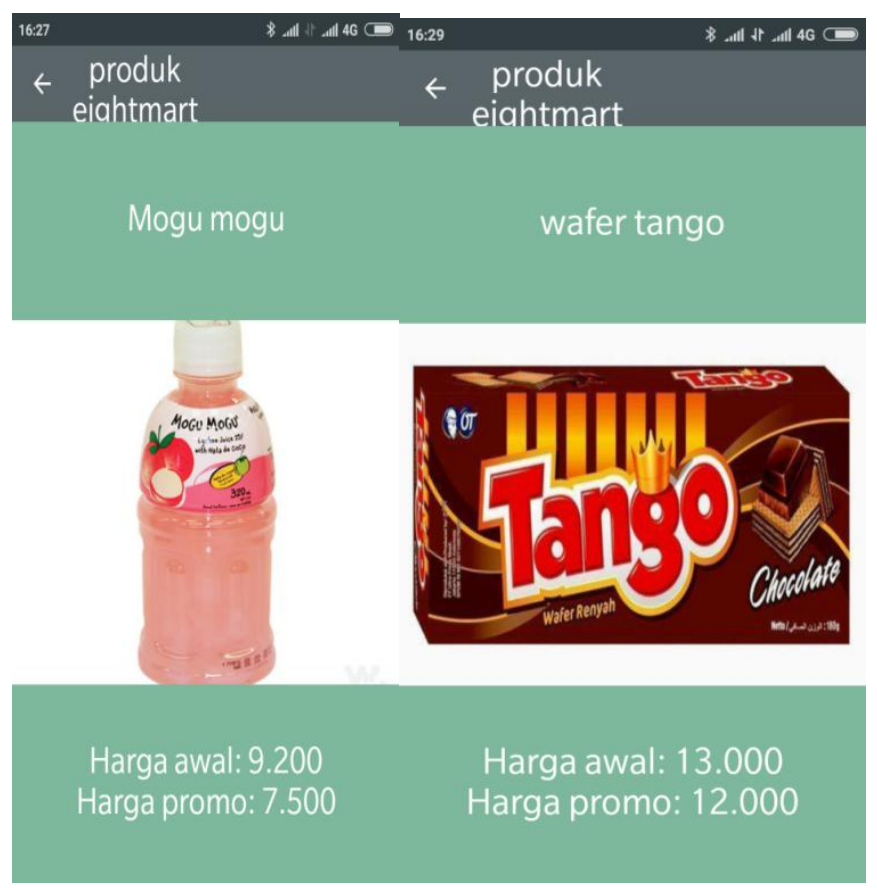

Gambar 11. Tampilan Halaman Promo Produk

\section{Implementation}

Pada tahap ini program yang sudah dibuat diujicoba dengan melakukan beberapa pengujian dengan menggunakan smarphone yang berbeda serta dapat menganalisa jarak yang bias dijangkau selama pengujian.

\section{Maintenance}

Selama pengujian terdapat beberapa kali kegagalan dalam implementasi sehingga dilakukan beberapa kali perbaikan pada program dan prangkat. Perubahan bisa terjadi karena adanya kesalahan yang muncul dan tidak terdeteksi saat pengujian atau terjadi karena perangkat lunak harus beradaptasi dengan lingkungan baru. Tahap pendukung atau pemeliharaan dapat mengulangi proses pengembangan mulai dari analisis spesifikasi untuk perbuahan perangkat lunak yang sudah ada, tapi tidak untuk membuat perangkat lunak baru.

Perangkat yang digunakan dalam pembuatan program atau aplikasi, dan pengujian pada smartphone peneliti dengan sistem operasi 6.0.1 marsmallow, dan smartphone pengunjung dengan sistem operasi 4.4 kitkat

Untuk mengetahui apakah fungsi-fungsi, masukan dan keluaran dari aplikasi tersebut sudah sesuai dengan spesifikasi yang dibutuhkan, dan untuk membuktikan berapa jarak maksimum yang di terima dengan memanfaatkan koneksi Bluetooth LE ini dengan dua smartphone yang berbeda yang memanfaatkan koneksi Bluetooth LE .

\section{KESIMPULAN}

Implementasi iBeacon dalam ruangan untuk penentuan lokasi dengan teknologi Bluetooth low energy pada Eighmart di universitas serang raya, diantaranya sebagai berikut:

1. Aplikasi ini dapat menampilkan promo produk, jarak dan petunjuk berupa gambar atau teks kemudian di tampilkan sesuai jarak yang terdekat pada iBeacon.

2. Jarak koneksi Bluetooth maksimum yang telah di uji pada kedua smartphone berbeda karena kecenderungan spesifikasi yang berbeda pula, karena penggunaan dalam Bluetooth LE ini minimum di tanamkan pada sistem operasi 4.4 kitkat, sehingga hasil kekuatan sinyal ternyata berbeda pada kedua sistem operasi tersebut. Pada aplikasi cubeacon yang ada di samsung J1 ace jangkauan sinyalnya yaitu sekitar 12,3 meter, dan pada samsung xiaomi redmi 4 a yaitu sekitar 16,5 meter.

4. Aplikasi yang dibuat hanya berfokus pada satu ruangan, tidak untuk dua atau lebih tempat.

\section{Saran}

1. Adanya pengembangan baru untuk program supaya keamanan dan fitur lebih menarik sehingga konsumen tertarik dalam melakukan transaksi belanja di Eighmart .

2. Diharapkan adanya pengembangan system agar aplikasi yang dikirim bisa menerima pemberitahuan dalam 
bonus atau promo yang ditawarkan kepada konsumen.

[1] C. Paper, L. Yang, B. Li, H. Li, and Y. Shen, "iBeacon / WiFi Signal Characteristics Analysis for Indoor Positioning Using iBeacon / WiFi Signal Characteristics Analysis for Indoor Positioning Using Mobile Phone,” no. June 2018, 2017, doi: 10.1007/978-981-10-4588-2.

[2] G. Conte, M. De Marchi, A. A. Nacci, V. Rana, and D. Sciuto, "BlueSentinel: A first approach using iBeacon for an energy efficient occupancy detection system," BuildSys 2014 - Proc. 1st ACM Conf. Embed. Syst. Energy-Efficient Build., no. September, pp. 11-19, 2014, doi: $10.1145 / 2676061.2674078$.

[3] A. A. N. and D. S. A. Corna, L. Fontana, "Occupancy Detection via iBeacon on Android Devices for Smart Building Management," Politec. di Milano, vol. 2, no. 1, pp. 625-632, 2015, doi: doi:10.7873/date.2015.0753.

[4] Y. G. Quanyu Wang and and M. T. , Lida Yang, "An Indoor Positioning System Based on iBeacon,” Z. Pan al. Trans. Edutainment XIII, LNCS 10092, vol. 3, no. 7, pp. 262-272, 2017, doi: 10.1007/978-3-662-54395-5_22.

[5] H. Z. 1, Y. L. 1, Hao Jiang 2, *, J. Z. 1, and Xiaoxuan Lu 1 and Lihua Xie 1, "BlueDetect: An iBeacon-Enabled Scheme for Accurate and Energy-Efficient Indoor-Outdoor Detection and Seamless Location-Based Service," Gert F. Trommer, vol. 8, no. 89, pp. 2-18, 2016, doi: doi.org/10.1007/978-3-662-54395-5_22.

[6] J. F. Ensworth, S. Member, M. S. Reynolds, and S. Member, "BLE-Backscatter : UltralowPower IoT Nodes Energy ( BLE ) Smartphones and Tablets," pp. 1-9, 2017.

[7] L. K. Yeung, J. Wang, Y. Huang, S. Lee, and K. Wu, "A Compact LTCC Bluetooth System Module with an Integrated Antenna," pp. 238-244, 2005, doi: 10.1002/mmce.

[8] S.Balaji, "WATEERFALLVs-V-MODEL Vs AGILE: ACOMPARATIVE STUDY ON SDLC," JITBM ARF, vol. 2, no. 1, pp. 26-30, 2012. 